\title{
Using Arctic driftwood at the interface of marine and terrestrial (paleo-)environmental research
}

Lena Hellmann 1,2, Ó. Eggertsson ${ }^{3}$ and U. Büntgen ${ }^{1,2,4}$

Mógilsá, Iceland, 27-30 April 2016

This workshop, on the use of Arctic driftwood as an interdisciplinary paleoenvironmental proxy, was held at the Icelandic Forest Research Institute Mógilsá, northwest of Reykjavik. Twentyone participants from 10 European and North American countries brought expertise in dendro-sciences, paleoclimatology and paleoecology, as well as archeology, history, oceanography and radiocarbon dating. The aim of the meeting was to build up a driftwood research network, by (1) the organization and coordination of future fieldwork, (2) the joining of forces towards a cross-disciplinary review paper, and (3) the collection of ideas for fundraising and proposal writing to facilitate international collaboration.

A first session on dendro-sciences and paleoecology provided an overview on the achievements of driftwood provenancing and dating, and its potential for reconstructing ocean-current dynamics and sea-ice variations. A second session reviewed proxy-based climate reconstructions for the Arctic, using examples of archeological driftwood research on the effects of wood decaying fungi to ancient wood use and tree-ring dating of archeological driftwood remains. A third session was dedicated to the reconstruction of relative sea-level changes, the effects of shrinking sea ice, the use of paleo-climatic estimates to constrain future climate predictions, as well as the current progress in radiocarbon dating.

Discussions emphasized the urgent need for cross-national sample exchange and free data access.

Finally, all participants agreed on writing an interdisciplinary review article about the current status and future perspective of Arctic driftwood research. The review paper

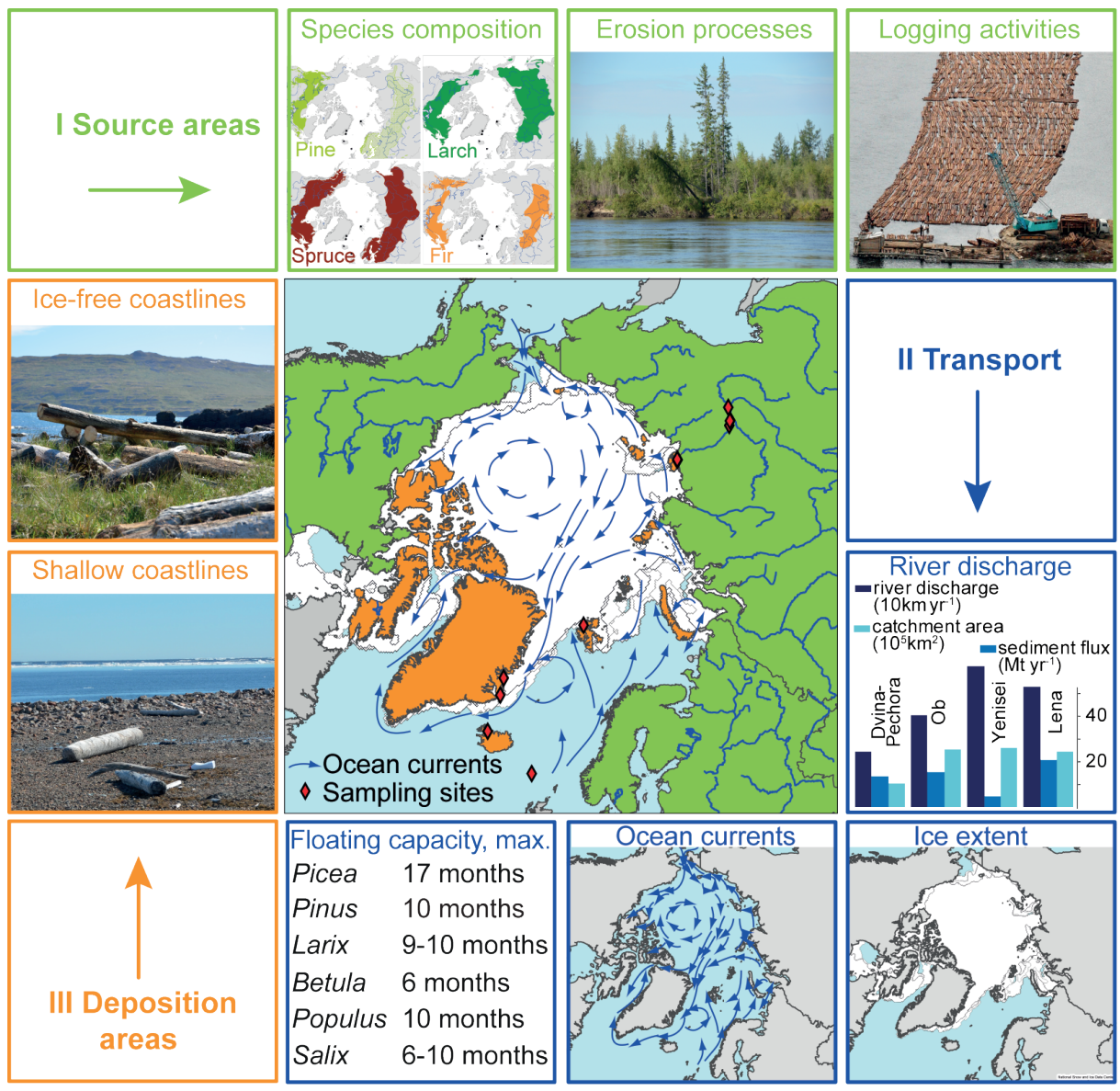

Figure 1: Schematic of the Arctic driftwood system. The amount and kind of driftwood material that starts its way to the Arctic Ocean is determined by species composition, erosion processes and logging activities in the boreal forest zone. How much wood is transported further, and in which direction, is influenced by boreal river discharge, sea-ice extent, ocean currents and the duration of transport, limited by the floating capacity. Deposition sites are generally shallow and ice-free coastlines. Map by the National Snow and Ice Data Center, USA. is motivated by the high sensitivity of the Arctic to even small climatic changes going along with short instrumental measurements and a sparse proxy-data coverage for the high-northern latitudes, which again constrains model predictions. Knowledge on past variations in sea-ice extent, ocean-current dynamics, relative sea-level change, biotic dispersal, transport times within the Arctic Ocean and the importance of driftwood for human settlements is scarce.

Figure 1 illustrates the complexity of the driftwood system and proves the relevance of an interdisciplinary research avenue. Arctic driftwood is a unique integral that combines various fields of research within the Arctic region by representing an easily accessible and relatively cheap environmental archive with a huge unused potential that needs to be explored. Existing methods and material from different disciplines of Arctic driftwood research will be provided in the review paper to show the potential of more reliable reconstructions extending prior to the period of instrumental measurements. This paper will further propose the need for Arctic driftwood as a cross-disciplinary proxy archive that can be used to supplement long-term observations and model simulations. The outlook will set priorities for future driftwood fieldwork and research activities, and promote Arctic driftwood as a contribution to multi-proxy approaches for a better understanding of past and present characteristics of the Arctic system.

The workshop created a new strong network of researchers working with this unique proxy archive that will be relevant for the PAGES initiative also in the future. A follow-up meeting on Arctic driftwood research has already been scheduled for May 2017.

\section{AFFILIATIONS}

'Swiss Federal Research Institute, WSL, Birmensdorf, Switzerland

${ }^{2}$ Oeschger Centre for Climate Change Research, Bern, Switzerland

${ }^{3}$ Iceland Forest Service Mógilsá, Reykjavik, Iceland ${ }^{4} \mathrm{Global}$ Change Research Centre AS CR, Brno, Czech Republic

\section{CONTACT}

Lena Hellmann: lena.hellmann@wsl.ch 